\title{
Typification of names in the Sesleria juncifolia species complex (Poaceae)
}

\author{
ROMEO DI PIETRO ${ }^{1, *}$, NEVENA KUZMANOVIĆ ${ }^{2}$, DUILIO IAMONICO ${ }^{1}$, LIA PIGNOTTI ${ }^{3}$, ZOLTAN \\ BARINA $^{4}$, DMITAR LAKUŠIĆ ${ }^{2} \&$ ANTUN ALEGRO \\ ${ }^{1}$ Department PDTA, Sapienza University of Rome, Via Flaminia, 72, 00196 Rome, Italy. Email: romeo.dipietro@uniromal.it, \\ d.iamonico@yahoo.it \\ ${ }^{2}$ Institute of Botany and Botanical Garden Jevremovac, Faculty of Biology, University of Belgrade, Takovska 43, 11000 Belgrade, \\ Serbia.Email.nkuzmanovic@bio.bg.ac.rs,dlakusic@bio.bg.ac.rs \\ ${ }^{3}$ Naturhistorisches Museum, Burgring 7, 1010, Wien, Austria. Email: lia.pignotti@NHM-WIEN.AC.AT \\ ${ }^{4}$ Department of Botany, Hungarian Natural History Museum, P.O. Box 222, Könyves Kálmán körút 40, 1476 Budapest, Hungary. \\ Email: barina@bot.nhmus.hu \\ ${ }^{5}$ Department of Botany, Faculty of Science, University of Zagreb. Marulićev trg 20/II, 10000 Zagreb, Croatia. \\ Email: antun.alegro@biol.pmf.hr \\ "Author for correspondence
}

\begin{abstract}
The nomenclature of the linear-leaved species of the Sesleria juncifolia complex is one of the topics of ongoing research on the taxonomy, genetic variation, and coenology of the genus Sesleria. This paper deals with the typification of five names belonging to the $S$. juncifolia complex that are widely used in the taxonomical and phytosociological literature. The holotype of S. juncifolia Suffren has been located. The names S. interrupta, S. juncifolia Host, and S. tenuifolia are lectotypified. A neotype is selected for $S$. ujhelyi. Images for all type specimens are provided, including those for members of the complex that are already validly typified (S. kalnikensis, S. albanica, S. apennina, S. calabrica).
\end{abstract}

Key words: Amphi-Adriatic taxa, Apennine, Balkans, Europe, lectotype, nomenclature, Sesleria

\section{Introduction}

Sesleria Scopoli (1760: 63) is a genus of about 30 species (27 according to Deyl (1980), 33 according to Strgar (1981)), which form several groups of closely related and morphologically similar species (Clayton \& Renvoize 1999). The genus has a mainly European distribution with extensions in northern Africa (Morocco) and near West Asia (Deyl 1946, Maire 1955, Valdés \& Scholz 2009), whereas the highest diversity occurs in the Balkans (where $79 \%$ of known species occur, and $49 \%$ are endemic) and in the Apennines (50\% of known species, 44\% endemic) (Deyl 1946, 1980, Ujhelyi 1965, Strgar 1981, Trombetta et al. 2005). Sesleria species are important in characterizing the coenological and physiognomical features of the mountain landscapes of central and southern Europe. Several Sesleria species are dominant in the high altitude zones, where they form various types of dry grasslands and are included in syntaxa at various ranks (e.g., LeontopodioSeslerietum Blasi, Di Pietro \& Pelino 2005, Seslerion apenninae Furnari in Bruno \& Furnari 1966, Seslerietalia tenuifoliae Horvat 1930). The names of the highest ranks (class) of the syntaxonomical framework for the high-altitude grassland vegetation of central and southern Europe bear epithets based on this genus (Elyno-Seslerietea Braun-Blanquet 1948, Festuco-Seslerietea Barbero \& Bonin 1969).

The $S$. juncifolia complex is one of the most characteristic south-eastern European Sesleria complexes, typically defined by linear acute and pungent leaves and dense reticulate-fibrous basal leaf sheaths (Deyl 1946, 1980). It ranges over the Balkans and the Apennines where it has an extremely wide ecological amplitude, distributed from sea level (e.g., cliffs of Porozina, and Omis in Croatia) to the alpine belt of the 


\section{Acknowledgments}

We acknowledge the financial support provided by the Serbian Ministry of Education, Science and Technological Development (project no. 173030) and the Italian Ministry of Instruction, University and Research (Ricerche d'Ateneo 2012 n. C26A12PJJ7). The work of Z.B. was partially supported by OTKA104443 grant. Support from the SYNTHESYS Project (http://www.synthesys.info/), which is financed by European Community Research Infrastructure Action under the FP7 "Capacities" Program, is also acknowledged (project HU-TAF 2956 to N. Kuzmanović). Special thanks to Moreno Clementi for his help in the search of Visiani specimens and manuscripts and to Adriano Soldano for help with some nomenclatural aspects. Constructive comments from two anonymous reviewers and the editor, Jeffery Saarela, are greatly acknowledged. Finally, thanks to the Directors and Curators of the Herbaria consulted for permission to reproduce the images of the types, and to Nejc Jogan for his help in the search of S. ujhelyii typus.

\section{References}

Alegro, A. (2007) Sistematika i rasprostranjenost kompleksa Sesleria juncifolia na području Dinarida. Dissertation, Faculty of Mathematics and Natural Sciences, University of Zagreb, 132 pp.

Arduino, P. (1764) Sesleria elongata. Petri Harduini Veronensis Horti publici patavini custodis Animadversionum botanicarum specimen alterum. Ex Typographia Sansoniana, Venetiis, 20 pp.

Barbero, M. \& Bonin G. (1969) Signification biogéographique et phytosociologique des pelouses échorchées des massifs méditerranéens nord-occidentaux, des Apennins et des Balkans septentrionaux (Festuco-Seslerietea). Bulletin de la Société Botanique de France 116: 247-248.

Blasi, C., Di Pietro, R., Fortini, P. \& Catonica, C. (2003) The main plant community types of the alpine belt of the Apennine chain. Plant Biosystems 137 (1): 83-110. http://dx.doi.org/10.1080/1126350031233135136

Blasi, C., Di Pietro, R. \& Pelino, G. (2005) The vegetation and landscape of alpine belt karst-tectonic basin in central Apennines. Plant Biosystems 139: 357-385. http://dx.doi.org/10.1080/11263500500350150.

Braun-Blanquet, J. (1948) La Végétation alpine des Pyrénées Orientales, étude de phyto-sociologie comparée. Consejo superior de Investigaciones Científicas, Barcelona.

Bruno, F. \& Furnari, F. (1966) Excursion de la société internationale de phytosociologie dans les Abruzzes (Apennins centraux). Notiziario Fitosociologico Italiano 3: 1-50.

Catorci, A., Gatti, R. \& Ballelli, S. (2007) Studio fitosociologico della vegetazione delle praterie montane dell'Appennino maceratese (Italia centrale). Braun-Blanquetia 42: 101-143.

Clayton, W.D. \& Renvoize, S.A. (1999) Genera Graminum: Grasses of the World. Royal Botanic Garden Kew, Kew, 389 pp.

Clayton, W.D., Govaerts, R., Harman, K.T., Williamson, H. \& Vorontsova, M. (eds.) (2013) World Checklist of selected plant names. Available from: http://apps.kew.org/wcsp/namedetail.do?name_id=442057 (accessed 10 July 2013).

Conert, H. J. (1992) Sesleria Scop. In: Hegi, G. (ed.) Illustrierte Flora von Mitteleuropa Ed. 2 1(3), Parey, Berlin, pp. $473-486$.

Conti, F., Abbate, G., Alessandrini, A. \& Blasi, C. (eds.) (2005) An annotated checklist of the Italian vascular flora. Palombi \& Partner, Roma, 420 pp.

Deyl, M. (1946) Study of the genus Sesleria. Opera Botanic Čechica 3: 1-246.

Deyl, M. (1980) Sesleria Scop. In: Tutin, T.G., Heywood, V.H., Burges, N.A., Moore, D.M., Valentine, D.H., Walters, S.M. \& Webb, D.A. (eds.) Flora Europea (Alismataceae to Orchidaceae) 5. Cambridge University Press, Cambridge, pp. 173-177.

Di Pietro, R. (2007) Taxonomic features of Sesleria calabrica (Poaceae), a neglected species from Southern Italy. Folia Geobotanica 42: 289-313. http://dx.doi.org/10.1007/BF02806468

Di Pietro, R. (2010) Phytosociological features of Sesleria calabrica (Poaceae), an endemic species of Pollino-Orsomarso mountains (southern Italy). Acta Botanica Gallica 157 (3): 539-554. http://dx.doi.org/10.1080/12538078.2010.10516229

Di Pietro, R., D'Amato, G. \& Trombetta, B. (2005) Karyology and distribution of Sesleria tenuifolia complex (Poaceae) in the Italian Peninsula. Nordic Journal of Botany 23: 615-623. http://dx.doi.org/10.1111/j.1756-1051.2003.tb00442.x

Foggi, B., Signorini, M. \& Vitek, E. (2004) Types of Festuca (Gramineae) names in the herbarium W: types from Host's herbarium. Annalen Des Naturhistorischen Museums In Wien. Serie B, Fuer Botanik Und Zoologie 105b: 597-612.

Grisebach, A. \& Schenk, A. (1852) Iter Hungaricum anno 1852, susceptum, Beiträge zur Systematik der ungarischen Flora. 
Wiegmann's Archiv für Naturgeschichte 18(1): 361.

Horvat, I. (1930) Vegetacijske studije o hrvatskim planinama. I. Zadruge na planinskim goletima- Rad Jugoslovenske akademije znanosti i umjetnosti 238: 1-96.

Horvat, I., Glavac, V. \& Ellemberg, H. (1974) Vegetation Sudosteuropas. Fischer Verlag, Stuttgart, 768 pp.

Host, N.T. (1802) Icônes et Descriptiones Graminum austriacorum 2. M.A. Schmidt, Vindobona, 72 pp.

Host, N.T. (1809) Icônes et Discriptiones Graminum austriacorum 4. M.A. Schmidt, Vindobona, 58 pp.

IPNI (2012) The International Plant Name Index. Available from: www. IPNI.org/index.html (accessed 05 July 2013).

Jarvis, C.E. (2007) Order out of Chaos; Linnaean Plant Names and their Types. Linnean Society of London and the Natural History Museum, London, 1016 pp.

Jávorka, S. (1911) Egy fel nem ismert Sesleriánkról. Über eine verkannte Sesleria. Magyar Botanikai Lapok 10: 311-314.

Kováts, D. (1984) Poaceae type specimens of Herbarium Carpato-Pannonicum in Budapest II. (Calamagrostis-Sesleria). Studia Botanica Hungarica 17: 61-68.

Kuzmanović, N., Comanescu, P., Frajman, B., Lazarević, M., Paun, O., Schönswetter, P. \& Lakušić, D. (2013) Genetic, cytological and morphological differentiation within the Balkan-Carpathian Sesleria rigida sensu Fl. Eur. (Poaceae): A taxonomically intricate tetraploid-octoploid complex. Taxon 62(3): 458-472. http://dx.doi.org/10.12705/623.13

Lancioni, A., Facchi, J. \& Taffetani F. (2011) Syntaxonomical analysis of the Kobresio myosuroidis-Seslerietea caeruleae and Carici rupestris-Kobresietea bellardii classes in the central southern Apennines. Fitosociologia 48(1): 3-21.

Linnaeus (1753) Species Plantarum. Laurentius Salvius, Tomus I, Stockholm, 560 pp.

Maire, R. (1955) Flore de L'Afrique du Nord. Lechevalier éd., Paris. NUMBER OF PAGES?

Martinčič, A., Wraber, T., Jogan, N., Podobnik, A., Turk, B., Vreš, B., Ravnik, V., Frajman, B., Krajšek, S.S., Trčak, B., Bačič, T., Fischer, M.A., Eler, K. \& Surina, B. (2007) Mala flora Slovenije. Ključ za določanje praprotnic in semenk. Četrta, dopolnjena in spremenjena izdaja. Tehniška založba Slovenije, Ljubljana, 967 pp.

McNeill, J., Barrie, F.R., Buck, W.R., Demoulin, V., Greuter, D.L., Hawksworth, D.L., Herendeen, P.S., Knapp, S., Marhold, K., Prado, J., Proud'Homme van Reine, W.F., Smith, J.F. \& Wiersema, J.H. (eds.) (2012) International Code of Nomenclature for algae, fungi and plants (Melbourne Code): Adopted by the Eighteenth International Botanical Congress, Melbourne, Australia, July 2011. Regnum Vegetabile 154: 1-208.

Moretti, G. (1826) Il botanico italiano; ossia, Discussioni sulla flora italica. Stamperia Fusi e Comp., Pavia, 44 pp.

Nikolič, T. (ed.) (2006) Flora Croatica baza podataka. Available from: http://hirc.botanic.hr/fcd (accessed 10 July 2013).

Pignatti, S. (1982) Flora d'Italia 3. Edagricole, Bologna, pp. 772.

Reichenbach, L. (1931) Flora Germanica excursoria. Carolum Cnobloch, Lipsiae, pp. 446.

Röhling, J.C. Mertens, F.C. \& Koch W.D.J. (1823) Deutschlands Flora Ed. 3, 1. F. Wilmans, Frankfurt am Main, 891 pp.

Schrader, H.A. (1806) Flora Germanica. Henricum Dieterich, Gottingae, 432 pp.

Schur, P.J.F. (1856) Ueber die siebenbu?rgischen Sesleriaceen. Beitra?ge zur Kenntniss des Florengebietes Siebenbu?rgen 6: 191-214.

Schur, P.J.F. (1866) Enumeratio Plantarum Transilvaniae. Gulielmum Braumuller, Vindobonae, 984 pp.

Scopoli, L. (1760) Flora Carniolica exhibens plantas Carniolae indigenas. Joannis Thomae Trattner, Viennae, 607 pp.

Strgar, V. (1981) Die Sippenstruktur von Sesleria auf der Balkanhalbinsel. Botanische Jahrbücher für Systematik 102: 215-224.

Strgar, V. (1982) Sesleria ujhelyii spec. nova. Biološki Vestnik 30: 155-170.

Suffren, P. (1802) Principes de Botanique, suivis d'un Catalogue des plantes du Friaul et de la Carnia. Antonine Rosa, Venise, $208 \mathrm{pp}$.

Thiers, B. (2013, continuously updated). Index Herbariorum: A global directory of public herbaria and associated staff. New York Botanical Garden's Virtual Herbarium. The New York Botanical Garden. Available from: http://sweetgum.nybg.org/ ih/ (accessed 22 July 2013).

Trombetta, B., Granati, A., D’Amato, G., Sabina, R., Martelli, G. \& Di Pietro, R. (2005) Un approccio integrato (tassonomico, biosistematico, fitosociologico) allo studio del genere Sesleria Scop. nell'Appennino (An integrate approach (taxonomic, bio-systematic, phytosociological) to the study of genus Sesleria Scop. in the Apennines). Informatore Botanico Italiano 37: $58-59$.

Ujhelyi, J. (1959a) Species Sesleriae generis novae. Feddes Repertorium Specierum Novarum Regni Vegetabilis 62: 59-70. http://dx.doi.org/10.1002/fedr.19590620108

Ujhelyi, J. (1959b) Revision des especies du genre "Sesleria" en Italie. Webbia 14: 597-614.

Ujhelyi, J. (1965) Sesleriinae. In: Meusel, H., Jäger, E. \& Weinert, E. (eds.) Vergleichende Chorologie der Zentraleuropäischen Flora 1/1. Jena, G. Fischer Verl., pp. 90-91.

Valdés, B. \& Scholz, H. (2009) Poaceae (pro parte majore). In: Euro+Med Plantbase - the information resource for EuroMediterranean plant diversity. Available from: http://ww2.bgbm.org/EuroPlusMed/PTaxonDetail.asp?NameId=141824\&PTRefFk=7100000 (accessed 10 July 2013).

Visiani, R. (1842) Flora Dalmatica 1. Apud Fridericum Hofmeister, Lipsiae, 252 pp. 